\title{
A Study of Iranian High School English Textbooks Based on the Standard Criteria
}

\author{
Elahe Ghorbanchian (Corresponding author) \\ Faculty of Foreign Languages, University of Isfahan, Isfahan 8174673441, Iran \\ Manijeh Youhanaee \\ Faculty of Foreign Languages, University of Isfahan, Isfahan 8174673441, Iran \\ Hossein Barati \\ Faculty of Foreign Languages, University of Isfahan, Isfahan 8174673441, Iran
}

\begin{abstract}
This study was an attempt to evaluate Iranian high school English textbooks in terms of vocabulary, grammatical structures and compatibility between reading comprehension texts and grammar exercises. Readability formula and experts' judgment were used to ensure that high school textbooks, English American headway and English American file books were at the same level of difficulty.The findings revealed that, there were a significant lack of compatibility between the grammatical structures and reading comprehension passages in each lesson and also between high school textbooks and English American headway and English American file books in terms of the order of presentation and content.
\end{abstract}

Index Terms — high school textbooks, readability formula, material evaluation, expert's judgment

\section{INTRODUCTION}

\section{Textbooks}

Textbooks have a crucial role in both teaching and learning process. In other words, there are many opinions among teachers and learners in relation to the main role of textbooks. Hutchinson and Torres (1994) in their article asked the reason that why teachers and learners use textbooks. The result for the learner showed that a learner saw the textbooks as a guide that aids the learners to organize their learning in both outside and inside the classrooms. In other words textbooks help learners to find their way in a durable process.

The result for the teachers showed that the teachers consider textbooks as a classroom directorship instrument for communication that exists between teacher and students. Based on teacher perceptions, a textbook retains time give orientation to the teachers program. Not only it gives direction to the class but also gives confidence and security to the teachers.

In the EFL classroom, materials are an inseparable part of the curriculum. They are the most noticeable characteristic of a teacher's approach, and can aid greatly to a sequence's syllabus. O'Neill (1982) provides 4 rationalizations for the use of textbooks. Firstly, a large percentage of a textbooks material can be proper for students needs, even if not precisely planned for them. Secondly, textbooks let students think about future, or recharge themselves with past lessons. They eliminate the factor of disbelief in student's expectations. Thirdly, textbooks have the concrete feature of presenting material which is well-organized in reasonable form. Finally, and I consider most importantly, well organized textbooks permit for managing and alteration by the teacher, as well as enabling students to construct unstructured dealings in the classrooms.

According to O'Neill, "Since language is a device for creating what people need and want to say naturally, a great deal must rely on natural, inventive dealings in the classroom." O’Neill (1982, p, 111). Textbooks should be reachable to a series of students, irrespective of their learning ends, along with being flexible to the multiplicity of teachers and teaching approaches.

Textbooks are chief properties for teachers in supporting students to learn every matter including English. They are the underpinning of school training and the major spring of information for teachers. In Iran, in practice textbooks function as the root for much of the language input learners obtain and the language practice that occur in the classroom. For the EFL learners, the textbook becomes the main source of exchange they have with the language away from the input provided by the teacher. Hutchinson and Torres (1994) propose that the textbook is an almost worldwide constituent of English language teaching and no teaching-learning situation, it seems, is comprehensive until it has its appropriate textbook.

Bearing in mind the manifold roles of textbooks in ELT, Cunningsworth (1995) implied a textbook as a supply in donating the material successively a source for learners to practice and carry out the activities. Still do they offer the learners with a reference source on grammar as well as vocabulary and pronunciation. to keep abreast, textbooks function as a syllabus and a self-study source for learners. Therefore they employ a support for the amateur teachers 
who have in confidence yet to achieve. Thus, it can be uttered that the fundamental role of textbooks is to be at the service of teachers and learners but not their boss.

\section{RESEARCH QUESTIONS}

1. Are Iranian textbooks in line with the standard text books in terms of the compatibility of passages and the structures taught in each unit as opposed to standards textbooks?

2. Are structures used in Iranian high school textbooks in line with the norms common in standard grammar textbooks?

\section{METHOD}

\section{A. Instrument}

\section{Textbooks}

The textbooks used in this study were of three types. The first group consisted of 4 textbooks corresponding to four levels of high school. The second group was American English File series and American English Headway series. As we know there are lots of textbooks available in the market such as: top notch series, interchange series and etc, but these two series serve as a compatible criterion for comparing the presentation pattern of the structure in high school books. The third group was Modern English used as a standard against which the two other groups were evaluated. To ensure that these textbooks are at the same level of difficulty as those of high school two measures were taken. In the first place, the Flesch Reading Ease Readability Formula was run on both high school textbooks passages and those of the target textbooks. In doing so reading three passages of each text book were chosen as the basis of the comparison. The scale through which readers and texts are graded is as below:

90-100: very easy

80-89: easy

70-79: fairly easy

60-69: standard

50-59: fairly difficult

30-49: difficult

0 -29: very confusing

Table 3.2 below shows the details of the readability formula results.

TABLE 3.2.

THE RESULT OF READABILITY EASE FORMULA

\begin{tabular}{|l|l|l|l|}
\hline Texts & American Headway 1 & American File 1 & High school 1 \\
\hline Text 1(beginning) & 65 & 70 & 68 \\
\hline Text2 (middle) & 66 & 64 & 71 \\
\hline Text 3 (end) & 68 & 63 & 69 \\
\hline & American Headway 2 & Hmerican File 2 & 69 \\
\hline Text 1(beginning ) & 67 & 62 & 63 \\
\hline Text2( middle) & 65 & 69 & 65 \\
\hline Text 3(end ) & 66 & 66 & High school 3 \\
\hline & American Headway 3 & 61 \\
\hline Text 1(beginning) & 59 & American File 3 & 65 \\
\hline Text2 (middle) & 57 & 57 & 59 \\
\hline Text 3 (end) & 55 & 58 & Pre-university \\
\hline & American Headway 4 & 56 \\
\hline Text 1(beginning) & 52 & American File 4 & 55 \\
\hline Text2 (middle) & 49 & 56 & 47 \\
\hline Text 3 (end) & 54 & 53 & 55 \\
\hline
\end{tabular}

As it is clear from Table 3.2, the readability index of each level of high school passages matched those of American Headway and American File on average.

In the second place, 5 teachers with 5 years experience of teaching the mentioned textbooks were asked to judge the difficulty level of the chosen text and to check the match between the texts in terms of level of difficulty. They all agreed that more or less texts are of the same level of difficulty.

High school textbooks were compared in terms of the order in which the structures were presented and also the ways through which learners were exposed to the structures. This comparison was done by the researcher through a meticulous and planned procedure. There is also an intra comparison regarding the establishing a match between the structures presented in the passages in high school books and the structures presented in the grammar sections of the same books. Moreover the same comparison was done to check the match between the structures taught in each unit and the passage American Headway and American File.

B. The Procedure for the Main Study 
Regarding the first question, the researcher tried to investigate the correspondence between the grammatical structures used in the passages and those in the grammar section of the same books. In so doing the number of the grammatical structures used in the text was used as a criterion for estimating the percentage of the correspondence.

The second question required the researcher to compare the order of the presentation of grammar in high school textbooks and that of American headway and American file series. For this purpose, each level of high school was matched with one level of the mentioned textbooks, and the whole presentation pattern of grammar was compared with that of Modern English. The comparison was based on the order of presentation in case of difficulty and the way grammar was presented. Table 2 shows the order and details of the correspondence of the textbooks.

TABLE3.3.

ORDER AND DETAILS OF TEXTBOOKS

\begin{tabular}{|l|l|}
\hline textbooks & Criterion for comparison \\
\hline High school level 1 & English American file 1, American headway 1 \\
\hline High school level 2 & English American file 2, American headway 2 \\
\hline High school level 3 & English American file 3, American headway 3 \\
\hline Pre-university & English American file 4,American headway4 \\
\hline All book & Modern English \\
\hline
\end{tabular}

\section{Data ANALYSIS}

\section{A. Compatibility between Structures Taught and the Structures Used in the Passages}

For addressing this question all high school books, American Headway and American File were analyzed and the agreement between the structures taught in each unit and the structured used in the same unit was checked and reported through percentage. For the ease of reporting the result of each analysis is shown in different tables. Table 4.2 shows the results of the analysis of the first book corresponding to the first level.

TABLE 4.3.

ANALYSIS OF THE FIRST BOOK OF HIGH SCHOOL

\begin{tabular}{|l|l|l|}
\hline lessons & Structure & Level of agreement \\
\hline One & could, had to & 10.7 \\
\hline Two & dummy subject, should & $8 \%$ \\
\hline Three & as+adj+as, comparison & $5 \%$ \\
\hline Four & comparison(irregular) & $0 \%$ \\
\hline Five & word order & $46 \%$ \\
\hline Six & tag questions & $4 \%$ \\
\hline Seven & that clause & $5 \%$ \\
\hline Eight & Passive & $8 \%$ \\
\hline Nine & present perfect & $7 \%$ \\
\hline
\end{tabular}

Table 4.3 indicates that to what extent passages of the first book contain the structures taught in each unit. The highest level of agreement was observed in lesson five and the lowest levels of agreement were observed in lesson four. Generally the agreement between the structures and their application in the passages was really low. This indicates lack of contextualization of the grammar prior to students' being exposed to the structures. The text of unit four is presented in appendix as an example to show the complete mismatch between the texts and structure.

The same analysis was done to American Headway 1. Table 4.4 shows the results of the analysis. 
TABLE 4.4

ANALYSIS OF AMERICAN HEADWAY 1

\begin{tabular}{|c|c|c|}
\hline lessons & Structure & Level of agreement \\
\hline One & Verb to be, possessive adj & $59 \%$ \\
\hline Two & Verb to be, negatives and short answers, possessive's & $64 \%$ \\
\hline Three & Present simple, questions and negatives & $57 \%$ \\
\hline Four & Present simple & $74 \%$ \\
\hline Five & $\begin{array}{l}\text { There is/are } \\
\text { How many... } \\
\text { Prepositions of place } \\
\text { Some and any } \\
\text { This, that, these, those }\end{array}$ & $43 \%$ \\
\hline Six & $\begin{array}{l}\text { Can/ can't } \\
\text { Was/ were } \\
\text { Could } \\
\text { Was born }\end{array}$ & $40 \%$ \\
\hline Seven & $\begin{array}{l}\text { Past simple regular verbs } \\
\text { Irregular verbs } \\
\text { Time expressions }\end{array}$ & $52 \%$ \\
\hline Eight & $\begin{array}{l}\text { Past simple } 2 \text { negative- ago } \\
\text { Time expressions }\end{array}$ & $63 \%$ \\
\hline Nine & $\begin{array}{l}\text { Count/ non count nouns } \\
\text { I like...? I'd like....? } \\
\text { A and some } \\
\text { Much and many }\end{array}$ & $53 \%$ \\
\hline Ten & $\begin{array}{l}\text { Present continuous } \\
\text { Whose is it? } \\
\text { Possessive pronouns }\end{array}$ & $57 \%$ \\
\hline Eleven & $\begin{array}{l}\text { Going to } \\
\text { Comparatives and superlatives }\end{array}$ & $62 \%$ \\
\hline Twelve & $\begin{array}{l}\text { Present perfect } \\
\text { Ever and never } \\
\text { Yet and just } \\
\text { Present perfect and past simple }\end{array}$ & $43 \%$ \\
\hline
\end{tabular}

Table 4.4 indicates that to what extent passages of American Headway 1 contain the structures taught in each unit. The highest level of agreement was observed in lesson four and the lowest level of agreement was observed in lesson six. Generally the agreement between the structures and their application in the passages was reasonable.

The same analysis was done to American File 1. Table 4.5 shows the results of the analysis. 
TABLE 4.5.

ANALYSIS OF AMERICAN FILE 1

\begin{tabular}{|c|c|c|}
\hline lessons & Structure & Level of agreement \\
\hline One & $\begin{array}{l}\text { Verb be }+ \text {, pronouns: I, you, etc. Verb be }- \text { and? } \\
\text { Possessive adj, my, your,, etc. } \\
\text { a/an, plurals, this/that/ these/ those }\end{array}$ & $37 \%$ \\
\hline Two & $\begin{array}{l}\text { Simple present+ and } \\
\text { Simple present? } \\
\text { a/ an }+ \text { jobs } \\
\text { possessive } s\end{array}$ & $34 \%$ \\
\hline Three & $\begin{array}{l}\text { Sdjectives } \\
\text { Telling the time, simple present } \\
\text { Adverbs of frequency } \\
\text { Prepositions of time }\end{array}$ & $54 \%$ \\
\hline Four & $\begin{array}{l}\text { Can/ can't } \\
\text { Like+ (verb+ ing) } \\
\text { Object pronouns: me, you, him, etc. } \\
\text { Possessive pronouns: mine, yours, etc. }\end{array}$ & $36 \%$ \\
\hline Five & $\begin{array}{l}\text { Simple past of be: was/ were } \\
\text { Simple past regular verbs } \\
\text { Simple past irregular verbs } \\
\text { Simple past regular and irregular }\end{array}$ & $67 \%$ \\
\hline Six & $\begin{array}{l}\text { There is/there are } \\
\text { There was/ the were } \\
\text { Present continuous } \\
\text { Simple present or present continuous? }\end{array}$ & $49 \%$ \\
\hline Seven & $\begin{array}{l}\text { a/ an, some/ any } \\
\text { how much/ how many? } \\
\text { Quantifiers: a lot, not much, etc. } \\
\text { Be going to(plans) } \\
\text { Be going to ( predictions) }\end{array}$ & $58 \%$ \\
\hline Eight & $\begin{array}{l}\text { Comparative adjectives } \\
\text { Superlative adjectives } \\
\text { Would like to/ like } \\
\text { Adverbs }\end{array}$ & $56 \%$ \\
\hline Nine & $\begin{array}{l}\text { Present perfect } \\
\text { Present perfect or simple past }\end{array}$ & $62 \%$ \\
\hline
\end{tabular}

According to Table 4.5 the highest levels of agreement belonged to lesson five. On the other hand the lowest level of agreement belonged to lesson two.

The same analysis was done to the second book of high school. Table 4.6 shows the results of the analysis.

TABLE 4.6.

ANALYSIS OF THE SECOND BOOK OF HIGH SCHOOL

\begin{tabular}{|l|l|l|}
\hline Lessons & Structure & Level of agreement \\
\hline One & past perfect & $3 \%$ \\
\hline Two & possessive pronoun & $4 \%$ \\
\hline Three & relative clauses & $14 \%$ \\
\hline Four & verb+infinitive, noun as modifier & $20 \%$ \\
\hline Five & article, wh-questions & $20 \%$ \\
\hline Six & $1^{\text {st }}$ conditional, reflexive & $4.3 \%$ \\
\hline Seven & $2^{\text {nd }}$ conditional & $0 \%$ \\
\hline
\end{tabular}

According to Table 4.6 the highest levels of agreement belonged to lesson four and five. On the other hand the lowest level of agreement belonged to lesson seven. It can be inferred that the second book is also suffering from lack of contextualization. The text of unit one is presented in appendix as an example to show the complete mismatch between the texts and structure.

The same analysis was done to American Headway 2. Table 4.7 shows the results of the analysis. 
TABLE 4.7.

ANALYSIS OF AMERICAN HEADWAY 2

\begin{tabular}{|c|c|c|}
\hline lessons & Structure & Level of agreement \\
\hline One & $\begin{array}{l}\text { Tenses, present, past, future } \\
\text { Questions, question words }\end{array}$ & $52 \%$ \\
\hline Two & $\begin{array}{l}\text { Present tenses, } \\
\text { Present simple } \\
\text { Present continuous } \\
\end{array}$ & $44 \%$ \\
\hline Three & $\begin{array}{l}\text { Past tenses } \\
\text { Past tenses } \\
\text { Past continuous } \\
\end{array}$ & $56 \%$ \\
\hline Four & $\begin{array}{l}\text { Quantity } \\
\text { Much and many } \\
\text { Some and any } \\
\text { A few, a little, a lot/ lots of } \\
\text { Something, someone, somewhere } \\
\text { Articles }\end{array}$ & $64 \%$ \\
\hline Five & $\begin{array}{l}\text { Verb patterns } \\
\text { Want/ hope to do } \\
\text { Enjoy/ like doing } \\
\text { Looking forward to doing } \\
\text { 'd like to do } \\
\text { Future intentions } \\
\text { Going to, will, and present continuous for } \\
\text { future }\end{array}$ & $53 \%$ \\
\hline Six & $\begin{array}{l}\text { What.... Like? } \\
\text { Comparative and superlative adjectives } \\
\text { As...as }\end{array}$ & $46 \%$ \\
\hline Seven & $\begin{array}{l}\text { Present perfect and past simple } \\
\text { For and since } \\
\text { Tense review }\end{array}$ & $62 \%$ \\
\hline Eight & $\begin{array}{l}\text { Have to } \\
\text { Should, must }\end{array}$ & $53 \%$ \\
\hline Nine & Time clauses, first conditional & $33 \%$ \\
\hline Ten & Passives & $57 \%$ \\
\hline Eleven & Second conditional, might & $62 \%$ \\
\hline Twelve & $\begin{array}{l}\text { Present perfect continuous, } \\
\text { Present perfect simple versus continuous }\end{array}$ & $48 \%$ \\
\hline
\end{tabular}

Table 4.7 indicates that the highest level of agreement belonged to lesson four and the lowest one belongs to lesson nine.

Table 4.8 shows the results of the analysis of the match between the structures and the passages of American file 2 .

TABLE 4.8 .

ANALYSIS OF AMERICAN FILE 2

\begin{tabular}{|c|c|c|}
\hline lessons & Structure & Level of agreement \\
\hline One & $\begin{array}{l}\text { Word order in question } \\
\text { Present continuous } \\
\text { Defining relative clauses }\end{array}$ & $43 \%$ \\
\hline Two & $\begin{array}{l}\text { Simple past: regular and irregular verbs } \\
\text { Questions with and without auxiliaries }\end{array}$ & $35 \%$ \\
\hline Three & $\begin{array}{l}\text { Going to, past continuous (future arrangements) } \\
\text { Review of tenses: present, past, and future }\end{array}$ & $42 \%$ \\
\hline Four & $\begin{array}{l}\text { Present perfect } \\
\text { Superlatives }\end{array}$ & $36 \%$ \\
\hline Five & $\begin{array}{l}\text { Uses of infinitive } \\
\text { Uses of the -ing form } \\
\text { Have to, don't have to, must, must not, can't }\end{array}$ & $39 \%$ \\
\hline Six & $\begin{array}{l}\text { If+ present; will+ base form } \\
\text { If + past; would+ base form } \\
\text { (second conditional) }\end{array}$ & $40 \%$ \\
\hline Seven & $\begin{array}{l}\text { Present perfect+ for and since } \\
\text { Used to } \\
\text { Passive }\end{array}$ & $35 \%$ \\
\hline Eight & Quantifiers, too, not enough & $54 \%$ \\
\hline Nine & $\begin{array}{l}\text { Past perfect } \\
\text { Reported speech }\end{array}$ & $46 \%$ \\
\hline
\end{tabular}

According to Table 4.8 the highest levels of agreement belonged to lesson eight. On the other hand the lowest level of agreement belonged to lesson two and lesson seven.

Table 4.9 below indicates the results of the analysis of the third textbook of the high school. 
TABLE 4.9.

ANALYSIS OF THE THIRD BOOK OF THE HIGH SCHOOL

\begin{tabular}{|l|l|l|}
\hline Lessons & Structure & level of agreement \\
\hline One & noun clauses, be going to & $4 \%$ \\
\hline Two & $\begin{array}{l}\text { be+adjective+for+onject+infinitive } \\
\text { gerund }\end{array}$ & $0 \%$ \\
\hline Three & Phrasalverb adjective/verb+preposition & $7.2 \%$ \\
\hline Four & $\begin{array}{l}\text { Verb+object+infinitive } \\
\text { Reported speech }\end{array}$ & $21 \%$ \\
\hline Five & $\begin{array}{l}\text { Present and past participle } \\
\text { Verb+adjective }\end{array}$ & $2.2 \%$ \\
\hline Six & Passive & $4 \%$ \\
\hline
\end{tabular}

As it is clear from Table 4.9 the problem of decontextualization and mismatch between structure and reading passage is still present in the third textbook. The highest level of agreement can be seen in lesson three which is 7.2 percent and the lowest level of agreement belonged to lesson two which is $0 \%$. The text of unit two is presented in appendix as an example to show the complete mismatch between the texts and structure.

The same analysis was done to American Headway 3. Table 4.10 shows the results of the analysis.

TABLE 4.10

ANALYSIS OF AMERICAN HEADWAY 3

\begin{tabular}{|c|c|c|}
\hline lessons & Structure & Level of agreement \\
\hline One & $\begin{array}{l}\text { Naming tenses } \\
\text { Present, past, present perfect } \\
\text { Auxiliary verbs } \\
\text { Questions and negatives } \\
\text { Short answers }\end{array}$ & $42 \%$ \\
\hline Two & $\begin{array}{l}\text { Present tenses } \\
\text { Simple and continuous } \\
\text { Passive }\end{array}$ & $54 \%$ \\
\hline Three & $\begin{array}{l}\text { Past tenses } \\
\text { Past perfect }\end{array}$ & $46 \%$ \\
\hline Four & $\begin{array}{l}\text { Advice, obligation, } \\
\text { Modal and related verbs }\end{array}$ & $44 \%$ \\
\hline Five & $\begin{array}{l}\text { Future forms } \\
\text { Will, going to, and present continuous }\end{array}$ & $53 \%$ \\
\hline Six & Information questions & $46 \%$ \\
\hline Seven & Present perfect, Simple and continuous & $52 \%$ \\
\hline Eight & $\begin{array}{l}\text { Verb }+ \text {-ing } \\
\text { Verb }+ \text { infinitive }\end{array}$ & $43 \%$ \\
\hline Nine & $\begin{array}{l}\text { Third conditionals } \\
\text { Might have done / could have done } \\
\text { Should have done }\end{array}$ & $53 \%$ \\
\hline Ten & $\begin{array}{l}\text { Noun phrases } \\
\text { Articles } \\
\text { Possessives } \\
\text { Reflexive pronouns and each other }\end{array}$ & $47 \%$ \\
\hline Eleven & $\begin{array}{l}\text { Modals of probability } \\
\text { Present } \\
\text { Past } \\
\text { Looks like / looks } \\
\text { Expressing disbelief } \\
\end{array}$ & $52 \%$ \\
\hline Twelve & $\begin{array}{l}\text { Reported speech } \\
\text { Reported thoughts } \\
\text { Reported questions } \\
\end{array}$ & $58 \%$ \\
\hline
\end{tabular}

Table 4.10 indicates that the highest level of agreement belongs to lesson twelve and the lowest one belongs to lesson one.

Table 4.11 shows the results of the analysis of the match between the structures and the passages of American file 3 . 
TABLE 4.11

ANALYSIS OF AMERICAN FILE 3

\begin{tabular}{|c|c|c|}
\hline lessons & Structure & Level of agreement \\
\hline One & $\begin{array}{l}\text { A) Present tenses: simple and continuous, } \\
\text { action and non-action verbs } \\
\text { B) past tenses: simple, continuous, perfect } \\
\text { C) future forms: going to, present continuous, } \\
\text { will }\end{array}$ & $33 \%$ \\
\hline Two & $\begin{array}{l}\text { A) present perfect and simple past } \\
\text { B) present perfect continuous } \\
\text { C) comparatives and superlatives }\end{array}$ & $38 \%$ \\
\hline Three & $\begin{array}{l}\text { A) must, have to, should ( obligation) } \\
\text { B) must, may, might, can't (deduction) } \\
\text { C) can, could, be able to (ability and } \\
\text { possibility) }\end{array}$ & $40 \%$ \\
\hline Four & $\begin{array}{l}\text { A) first conditional and future } \\
\text { Time clause }+ \text { when, until, etc. }\end{array}$ & $32 \%$ \\
\hline Five & $\begin{array}{l}\text { A) quantifiers } \\
\text { B) articles: a / an, the, no article } \\
\text { C) gerunds and infinitives }\end{array}$ & $40 \%$ \\
\hline Six & $\begin{array}{l}\text { A) Reported speech: statements, questions, } \\
\text { and commands } \\
\text { B) passive: be + past participle } \\
\text { C) relative clauses: defining and non-defining }\end{array}$ & $41 \%$ \\
\hline Seven & $\begin{array}{l}\text { A) third conditionals } \\
\text { B) tag questions, indirect questions } \\
\text { C) phrasal verbs }\end{array}$ & $36 \%$ \\
\hline
\end{tabular}

According to Table 4.11 the highest levels of agreement belonged to lesson six. On the other hand the lowest level of agreement belonged to lesson four.

The results of the analysis of pre-university book are presented in Table 4.12 bellow.

TABLE 4.12

ANALYSIS OF PRE-UNIVERSITY BOOK

\begin{tabular}{|l|l|l|}
\hline lessons & Structure & Level of agreement \\
\hline One & conjunction of time & $50 \%$ \\
\hline Two & bare infinitive, & $50 \%$ \\
\hline Three & adjective phrase & $2.5 \%$ \\
\hline Four & modification of adjectives & $2 \%$ \\
\hline Five & expressing contrast(while, whereas) & $8.8 \%$ \\
\hline Six & expressing purpose & $10 \%$ \\
\hline Seven & expressing contrast(although) & $6.2 \%$ \\
\hline Eight & Modals(can, may, might, could) & $2 \%$ \\
\hline
\end{tabular}

It can be inferred that in pre-university book the level of agreement seems higher, however the lack of match can still be observed. The first two units show a good deal of agreement which is 50 percent. Alternatively the lowest levels of agreement belong to lesson four and eight which is 2 percent.

Table 4.13 illustrates the analysis of the match between the reading passages and structures taught in American Headway 4. 
TABLE 4.13

ANALYSIS OF AMERICAN HEADWAY 4

\begin{tabular}{|c|c|c|}
\hline lessons & Structure & Level of agreement \\
\hline One & $\begin{array}{l}\text { The tense system } \\
\text { Simple, continuous, perfect } \\
\text { Active and passive } \\
\text { Informal language }\end{array}$ & $52 \%$ \\
\hline Two & $\begin{array}{l}\text { Present perfect } \\
\text { Simple and continuous } \\
\text { Being imprecise } \\
\text { Fillers }\end{array}$ & $34 \%$ \\
\hline Three & $\begin{array}{l}\text { Narrative tenses } \\
\text { Past simple, past continuous, past perfect } \\
\text { active and passive } \\
\text { News and responses } \\
\text { The use of like }\end{array}$ & $44 \%$ \\
\hline Four & $\begin{array}{l}\text { Questions and negatives } \\
\text { The question how come? }\end{array}$ & $43 \%$ \\
\hline Five & $\begin{array}{l}\text { Future forms } \\
\text { The word thing }\end{array}$ & $55 \%$ \\
\hline Six & $\begin{array}{l}\text { Expressions of quantity } \\
\text { Informal expressions of quantity }\end{array}$ & $56 \%$ \\
\hline Seven & $\begin{array}{l}\text { Modals and related verbs } 1 \\
\text { Declarative questions } \\
\text { Questions expressing surprise }\end{array}$ & $42 \%$ \\
\hline Eight & $\begin{array}{l}\text { Relative clauses } \\
\text { Participles } \\
\text { Adding a comment with which }\end{array}$ & $55 \%$ \\
\hline Nine & $\begin{array}{l}\text { Expressing habit } \\
\text { Be used to doing } \\
\text { Intensifying compounds }\end{array}$ & $56 \%$ \\
\hline Ten & $\begin{array}{l}\text { Modal auxiliary verbs } 2 \\
\text { Expression with modal verbs }\end{array}$ & $49 \%$ \\
\hline Eleven & $\begin{array}{l}\text { Hypothesizing } \\
\text { Expressions with if }\end{array}$ & $53 \%$ \\
\hline Twelve & $\begin{array}{l}\text { Articles } \\
\text { a/an, the, one, zero article } \\
\text { determiners } \\
\text { demonstratives and determiners }\end{array}$ & $57 \%$ \\
\hline
\end{tabular}

It can be said that according to Table 4.13 the highest level of agreement was observed in lesson twelve and the lowest level of agreement was observed in lesson two.

The same analysis was done to American File 4. Table 4.14 shows the results of the analysis.

TABLE 4.14

ANALYSIS OF AMERICAN FILE 4

\begin{tabular}{|c|c|c|}
\hline lessons & Structure & Level of agreement \\
\hline One & $\begin{array}{l}\text { A) review: question information } \\
\text { B) auxiliary verbs; the } \ldots \text { the } \ldots+ \\
\text { comparatives }\end{array}$ & $36 \%$ \\
\hline Two & $\begin{array}{l}\text { A) adjectives as nouns, adjective order } \\
\text { B) narrative tenses, past perfect continuous; } \\
\text { so/ such ... that }\end{array}$ & $37 \%$ \\
\hline Three & $\begin{array}{l}\text { A) passive (all forms), it is said that ..., he is } \\
\text { thought to } \ldots, \text { etc. } \\
\text { B) future perfect and future continuous }\end{array}$ & $42 \%$ \\
\hline Four & $\begin{array}{l}\text { A) unreal conditionals } \\
\text { B) past modals; }\end{array}$ & $49 \%$ \\
\hline Five & $\begin{array}{l}\text { A) gerunds and infinitives } \\
\text { B) used to, be used to, get used to }\end{array}$ & $47 \%$ \\
\hline Six & $\begin{array}{l}\text { A) articles } \\
\text { B) uncountable, plural, and collective nouns; } \\
\text { have something done } \\
\text { C) Quantifiers: all / every, etc. }\end{array}$ & $31 \%$ \\
\hline Seven & $\begin{array}{l}\text { A) structures after wish } \\
\text { B) clauses of contrast and purpose; whatever, } \\
\text { whenever, etc. } \\
\text { C) relative clauses }\end{array}$ & $36 \%$ \\
\hline
\end{tabular}

The highest level of agreement can be seen in lesson four which is 42 percent and the lowest level of agreement belonged to six which is $31 \%$.

B. Compatibility of High School Textbooks with Standard Textbooks 
This compatibility was checked through comparing high school textbooks, American headway series and American files series against Modern English book to determine the concordance of each series with a standard English grammar book.

TABLE 4.15

RESULTS OF COMPARING HIGH SCHOOL TEXTBOOKS, AMERICAN FILES AND AMERICAN HEADWAYS WITH MODERN ENGLISH

\begin{tabular}{|l|l|}
\hline Textbooks & Compatibility \\
\hline High school text books & $11.5 \%$ \\
\hline American headway series & $64.7 \%$ \\
\hline English American file series & $69.3 \%$ \\
\hline
\end{tabular}

Level of compatibility was defined as the degree to which the structures in each series are in line with those of Modern English in terms of order of presentation and inclusion of key grammatical points. As it can be seen American headway textbooks and English American files textbooks showed a higher level of compatibility than high school textbooks and this implies that American headway series and English American files are closer to standard English grammar books norms than high school textbooks.

In next step high school textbooks, American headway and English American files are compared in terms of order of presentation of structures and the way through which structures are presented.

This compatibility was checked through comparing high school textbooks and American Headway series as well as American File in terms of order of the presentation and the way through which structures are presented. Level of compatibility was defined as the degree to which the structures in each series are matched in terms of order of presentation and inclusion of key grammatical points.

\section{Order of presentation}

Regarding the above tables the grammatical volume of American file and American head way is more than high school books. In American files and American head way materials are supplied from simple to hard, but it is not true with high school books, furthermore all materials are unscrambled and do not follow a fair order.

\section{Method of presentation}

In American file and American head way all materials are presented in a contextualized way additionally there are formed focused exercises to practice grammatical points, however such materials are presented in a decontextualized way and there are no form focused exercises for follow up practices.

\section{CONCLUSION}

Referring to the first question of this study (see tables from 4.3 to 4.14 ), it can be detected that American Head way and American file series outstandingly introduced grammatical structures in passages providing adequate context to raise students' consciousness. Such presentation of target point is highly recommended in order to activate related schemata. On the contrary, none of the high school series applied such a procedure. In other words, high school books did not use the passages in order to raise students' consciousness. To keep abreast, it needs declaring that such problems indicate pitfalls in practical grammar teaching and thus leads students to receive limited input for target structures.

Referring to the second question of this study, there are two approaches as how to grade target points: The structuralism view and the functional notional approach. The former signifies that structures must be organized in accordance to the level of difficulty and the latter states that first a specific situation is presented and then a suitable structure to that situation be taught.

In a performed study showed that on high school books, American head way and American file series presented structure in accordance to structural view owing to the fact that grammar is presented in simple to complex, However none of the high school books applied neither of those approaches due to the fact that no order of presentation was observed and grammatical points were presented in a random order. Another point to state is the amount of grammatical points which are presented in American files and American head way books noticeably but such thing was not true with high school books. Presenting adequate grammatical contexts brings about curiosity for learners which is one of the most significant factors in motivating them to learn structures properly. Based on performed research, it was found that American head way and file series focus on the target points in all sections of each lessons such as Readings, Listening exercises, Conversations, Self-study exercises and Grammar spots are adequately related. By contrasts no adequate context for grammar presentation is given in high school books leading to teaching grammar decontextualized and coming up with major weakness ;i.e, lack of to activate schemata which is an indispensible part of teaching grammar, which nonexistence of such a factor leads to an awkward and imperfect grammatical knowledge, further down side for high school books is that they have got no reliance on variety of exercises in different situations enjoying a variety of practical grammars which the reverse is true with American head way and file series.

\section{REFERENCES}

[1] Allright, R. L. (1981). What do we want teaching materials for? ELT Journal, 36(1), 5-13.

[2] Ansary, H. \& Babaii, E.. Universal characteristics of EFL/ESL textbooks: The Internet TESL Journal, 8(2), available onlineat: http:/ iteslj. org/ Ansarytextbooks/February 2002. 
[3] Armbruster, B. B. and Anderson, T. H. (1990). Textbooks and curriculum International Encyclopedia of Educational Evaluation, (pp. 206-209). New York: Pergamon Press.

[4] Ayman, B. (1997). Evaluation of an English for academic purpose textbook: A Case Study. Unpublished master's thesis, METU, Ankara, Turkey.

[5] Benevento, J. (1984). Choosing and using textbooks Paper presented at the annual meeting of the American council on the teaching of foreign languages. Chicago. IL

[6] Breen, M.P and Candlin. C.N. (1987). Which materials? A consumer's and designer's guide. In L. E. Sheldon (ed), ELT Textbooks and Materials. Problems in Evaluation and Development, (pp. 13-28). Oxford: Modern English Publications.

[7] Brown, V. (1993). Decanonizing discourse: Textual analysis and the history of economic thoughts In W. Henderson, T. Dudley-Evans \& R. Backhouse (Eds.), Economics \& language (p 64-84).

[8] Bryd, P. (2001). Textbooks: Evaluation for selection and analysis for implementation. In M. Celce-Murcia (Ed.) Teaching English as a second or a foreign language (3rd ed.), pp. 415-427. Boston: Hienle \& Hienle Publishers.

[9] Bugmaster, R. (2005). Reading and reading skills. Modern English teacher 14 (2), 38-41.

[10] Common European Framework of Reference for Languages: learning, teaching and assessment, (2001) Council of Europe. Retrieved September 19, 2006, from http://www.coe.int/t/dg4/liguistic/source/framework_EN.pdf.

[11] Chambers, F. (1997). Seeking Consensus in Coursebook Evaluation. ELT Journal, .51(1),29- 35

[12] Chastain, K. (1971). The development of modern language skills: Theory to practice (pp.37384). Philadelphia. The Center for Curriculum Development, Inc.

[13] Coskuner, P. D. (2002). Evaluation of effectiveness of an ESP textbook. A Case Study. Unpublished master's thesis, METU. Ankara, Turkey.

[14] Cotteral, S. (2000). Promoting learner autonomy through the curriculum: principles for designing language courses. ELT Journal. 54(2) 109-115.133

[15] Cunningsworth, A. (1995). Choosing your coursebook. Oxford: Heinemann Publishers Ltd.

[16] Daoud, A. \& Celce-Murcia, M. (1979). Selecting and evaluating a textbook. In M. In M. Celce- Murcia and L. McIntosh (Eds.), Teaching English as a second or foreign language (pp. 302- 307). Cambridge, MA: Newbury House Publishers.

[17] Dougill, J. (1987). Not so obvious. In L. E. Sheldon (ed.) ELT Textbooks and Materials: Problems in Evaluation and development, (pp. 29-35). Oxford: Modern English Publications.

[18] Dubin. F. Olshtain, E. (1986). Course Design. Developing Programs and Materials for Language Learning. Cambridge: Cambridge University Press.

[19] Ellis, P. and Ellis, M. (1987). Learning by Design Criteria for ELF Coursebooks. In L. E. Sheldon (ed.) ELT Textbooks and Materials: Problems in Evaluation and Development, (pp. 90-98). Oxford: Modern English Publications.

[20] Ellis, R. (1997). The empirical evaluation of language teaching materials. ELT Journal, 51(1), (36-42).

[21] Garinger, D. (2005). Textbook evaluation. Retrieved October 18, 2005 from http://www.teflweb-j.org/v1n1/garinger.html.

[22] Genesee, F. (2001). Evaluation. In R. Carter, \& D. Nunan (Eds.), The Cambridge guide to teaching English to speakers of other languages (pp. 144-150). Cambridge: Cambridge university press.

[23] Grant, M. (1987). Making the most of your textbook. London: Longman.

[24] Harmer, J. (1996). The practice of English language teaching. London: Longman

[25] Hargreaves, A. (1989). Curriculum and assessment reform. Toronto: OISE Press

[26] Hinkel, E. (2006). Current perspectives on teaching four skills. TESOL Quarterly 40, (1), 109-125.

[27] Hong Xu, I. (2004). Investigating criteria for assessing ESL textbooks. Unpublished doctoral dissertation, University of Alberta, Edmonton, Canada.

[28] Huthchinson, T. (1987). What is underneath? An interactive view of the materials evaluation. In L. E. Sheldon (ed.), ELT textbooks and materials: Problems

[29] Hutchinson, T \& Torres, D. (1994). The textbook as agent of change ELT Journal, 48, 315-328.

[30] Jahangard, A. (2007). The evaluation of the EFL materials taught at Iranian public high schools. Karen's Linguistics Issues in evaluation and development, (pp. 37-44), Oxford: Modern English Publications

[31]_nözü, J. (1999). Criteria in selecting English language teaching coursebook: teachers' and students' point of view. Unpublished master's thesis, Çukurova University, Adana, Turkey.134

[32] Kanik, F. (2002). Evaluating the effectiveness of the ESP reading materials for 215 English for law course. Unpublished master's thesis, METU, Ankara, Turkey.

[33] Karababa, Z. C. (1993). _lkögretim 3. ve 5. sınıf Türkçe ve ngilizce ders kitaplarının incelenmesi ve karsılastırılması. Yayınlanmamıs doktora tezi, Ankara Universities, Ankara, Turkey.

[34] Little, D and Leni, D (1998). Learner autonomy: what and why? Retrieved September 20, 2006 from http://jaltpublications.org/tlt/filed/98/oct.

[35] Littlejohn, A. (1996). The analysis of language teaching materials: Inside the Trojan Horse. In B. 33.Tomlinson, (Ed.). Materials development in language teaching (pp. 191-213). Cambridge. Cambridge University Press.

[36] Mc Donough, J. and Shaw, C. (1993). Materials and method in ELT, Oxford: Blackwell Publishers Ltd.

[37] Mc Grath, I. (2006). Teachers' and learners' images for coursebooks. ELT Journal 60(2), 171-179.

[38] MEB Anadolu Lisesi (hazırlık sınıfı ve 9, 10, 11. sınıflar)_ngilizce dersi ögretim programı, (2002). MEB Ortaögretim Genel Müdürlügü. Milli Egitim Basımevi: Ankara.

[39] Nunan, D. (1997). Autonomy and independence in language learning. In P. Benson and P. Voller (ed.), Designing and adapting materials to encourage learner autonomy. UK: Addison Wesley Longman Ltd.

[40] Ornstein, A. C. and Hunkins, F. P. (1998). Curriculum: Foundations, principles and issues. USA: Allyn and Bacon.Oxford, L. R. (2001). Language learning styles and strategies. In M. Celce-Murcia (Ed.) Teaching English as a second or a foreign language (3rd ed.), (pp. 359-366). Boston: Hienle \& Hienle Publishers.

[41] Öztürk, M ve Yurttagüler, L (2003). Ders kitapları. Egitim reformu girisimi. Ankara

[42] Prabhu, N.S. (1987). Second Language Pedagogy. Oxford: Oxford University Press (pp. 94- 95). 
[43] O'Neill, R. (1982). Why use textbooks? ELT Journal, 36/2.

[44] Prator, C. H. (1991). Cornerstones of method and names for the profession. In M. Celce-Murcia (Ed) Teaching English as a second or foreign language (2nd ed), pp. 11-22. New York: Newbury House.

[45] Rea-Dickens, P. and Germaine, K. (1994). Evaluation. In Candlin and Widdowson (ed.), Oxford University Press.135.

[46] Riazi, A.M., \& Aryashokouh, A. (2007). Lexis in English textbooks in Iran: Analysis of exercises and proposals for consciousness-raising activities. Pacific Association of Applied Linguists, 11, 17,34).

[47] Richards, J. C. (2001). The role of textbooks in a language program. Cambridge University Press, Cambridge.

[48] Sheldon, L. E. (1998). Evaluating ELT textbooks and materials. ELT Journal, 42(4), 237-246.

[49] Sinclair, B. and Ellis, G. (1992). Survey: learner training in EFL coursebooks. ELT Journal, 42(2), 209-225.

[50] Skierso, A. (1991). Textbook selection and evaluation. In M. C. Murcia (ed.), Teaching English as a second or foreign language (pp. 432-453), Boston: Heinle and Heinle Publishers.

[51] Tomlinson, B (1998). Glossary of basic terms for materials development in language teaching and introduction. In B. Tomlinson (ed.), Materials development in language teaching. (pp. 1-24). Cambridge: Cambridge University Press.

[52] Ur, Penny (1996). A course in language teaching - practice and theory. Cambridge: Cambridge University Press.

[53] Williams, D. (1983). Developing criteria for textbook evaluation. ELT Journal, 37(3), 251-254.

[54] Widdowson, Henry G. (1998b) "Communication and Community. The Pragmatics of ESP." English for Specific Purposes 17/1 3-14.

[55] Willis, J. (1982). Teaching through English. England: Longman Group Ltd.

[56] Yakhontova, T (2001). Textbooks, contexts and learners. English for specific purposes, 20 (3), 397-415.

[57] Yumuk, A. (1998). A case study on evaluating the effectiveness of English language Support 201 course materials for Bureau Management and Secretarial Studies at Bilken. University. Unpublished doctoral dissertation, METU Ankara, Turkey.

[58] Zenger, W. F. (1982). Textbook evaluation: A guide and checklist. Sonataga.

[59] Procedia - Social and Behavioral Sciences Volume 3, 2010, Pages 36-44 An analytical evaluation of Iranian high school ELT textbooks from 1970 to the present : Akbar Azizifar Mansour Koosha Ahmad R. Lotfi Islamic Azad University, Isfahan, Iran

Elahe Ghorbanchian was born in Esfahan. She received her Bachelor's degree in English Language literature in Esfahan university in Iran and did her M.A in TEFL at University of Isfahan and now a PhD candidate in Esfahan university, And also presented a paper in local conference.

Manijeh Youhanaee holds a $\mathrm{PhD}$ in language and linguistics from the University of Essex. She has co-authored with Badrizadeh "A Descriptive Dictionary of Theories of Generative Grammar". She has published a number of articles on the teaching/ acquisition of different English syntactic properties by native speakers of Persian. She teaches MA and PhD courses in linguistics, generative grammar, TEFL and SLA. Her areas of interest include syntactic theory, acquisition of L2 \& L3 syntax and issues in teaching and learning English as a second/foreign language.

Hossein Barati works in the English department, University of Isfahan, where he is assistant Professor of Applied Linguistics. He has a PhD in Language Testing from University of Bristol, England and has been involved in research in language testing, program evaluation, reading strategies, and classroom discourse. He has published in areas of language testing and assessment, and language program evaluation. He is a member of a research project on Developing a new model of teaching to adult English non-majors at University of Isfahan, funded by University of Isfahan. He has also co-authored some publications on DIF in Iranian National University Entrance Exam (INUEE), 2007; Linguistic constraints and language teaching, 2008; and Cultural differences in EFL performance on cloze tests, 2010. Further a text-book "A step forward in English for intermediate EFL learners" is among his latest publications. He is currently working on "New plans for Teaching English to Iranian adult non-majors", "Teaching English to Iranian young learners" and "The consequential validity of high stakes tests in the Iranian context". 